\title{
Biocoenotic and habitat ordination of mud shrimp Upogebia pusilla Petagna, 1792 (Crustacea: Decapoda) settlements on the northern part of the Black Sea shelf (Crimean coast)
}

\author{
Биоџенотическая и биотопическая ординаџия поселений рака- \\ крота Upogebia pusilla Petagna, 1792 (Crustacea: Decapoda) на \\ северном участке шемьфа Черного моря (побережкье Крыма)
}

\author{
Nikolai K. Revkov*, Vitaliy A. Timofeev, Tatyana N. Revkova \\ Н.К. Ревков*, В.А. Тимофеев, Т.Н. Ревкова
}

\author{
A.O. Kovalevsky Institute of Biology of the Southern Seas of RAS, Nakhimov ave., 2, Sevastopol, 299011, Russia. \\ * Corresponding author. E-mail: nrevkov@yandex.ru \\ Федеральный исследовательский центр «Институт биологии южных морей им. А.О. Ковалевского РАН», пр. Нахимова, 2, \\ Севастополь, 299011, Россия. \\ *Автор, которому должна быть адресована корреспонденция. E-mail: nrevkov@yandex.ru
}

KEY WORDS: Upogebia pusilla, abundance, biomass, spatial distribution, biocoenotic complexes, EUNIS habitat classification, Black Sea, Crimea.

КЛЮЧЕВЫЕ СЛОВА: Upogebia pusilla, численность, биомасса, пространственное распределение, биоценотический комплекс, EUNIS habitat classification, Чёрное море, Крым.

ABSTRACT. The object of the study was the Black Sea Decapoda Upogebia pusilla Petagna, 1792 ("mud shrimp", "sea mole", upogebia), having a protective status in a number of the Black Sea countries. The work was based on expeditions materials from the database of the Benthos Ecology Department of the IBSS, collected in 1957-2013. The aim of this work was to assess the spatial distribution, biocoenotic and habitat ordination of $U$. pusilla Petagna, 1792 on the Black Sea shelf of Crimea. It was found in the depth range of 1-36 $\mathrm{m}$. The depth profile for the quantitative representation of $U$. pusilla habitats had two peaks: the first one was in relatively shallow and closed to strong wave impact areas as bay type in the depth range up to $6 \mathrm{~m}$, the second one was in offshore open waters relatively remote to the coast at depths $20-30 \mathrm{~m}$. The maximum values of the abundance and biomass of $U$. pusilla off the coast of Crimea do not exceed, respectively, 58 ind. $/ \mathrm{m}^{2}$ and $53 \mathrm{~g} / \mathrm{m}^{2}$. Mud shrimp formed settlements at the Crimean coast in such five biocoenotic complexes as Heteromastus filiformis + Bittium reticulatum (I); Upogebia pusilla + Abra segmentum + Loripes orbiculatus (II); Mytilaster lineatus + Pisidia longimana (III); Pitar rudis + Chamelea gallina + Upogebia pusilla (IV) and Mytilus galloprovincialis (V). According to the EUNIS habitat classification the description of $U$. pusilla habitats on the Crimean Black Sea shelf was given.

How to cite this paper: Revkov N.K., Timofeev V.A., Revkova T.N. 2021. Biocoenotic and habitat ordination of mud shrimp Upogebia pusilla Petagna, 1792 (Crustacea: Decapoda) settlements on the north- ern part of the Black Sea shelf (Crimean coast) // Arthropoda Selecta. Vol.30. No.4. P.531-539. doi: 10.15298/arthsel.30.4.08

РЕЗЮМЕ. Объектом исследования являлся черноморский представитель отряда Decapoda - Upogebia pusilla Petagna, 1792 («грязевая креветка», «морской крот», упогебия), имеющая охранный статус в ряде черноморских стран. Работа выполнена на основе анализа экспедиционных материалов из базы данных отдела Экологии бентоса ФИЦ ИнБЮМ, собранных в 1957-2013 гг. Целью настоящей работы было уточнение пространственного распределения и оценка биоценотической и биотопической ординации поселений Upogebia pusilla Petagna, 1792 у черноморских берегов Крыма. Её поселения отмечены в диапазоне глубин от 1 до 36 м. Глубинный профиль местообитаний U. pusilla имел два пика количественного развития: первый находился в относительно неглубоких и закрытых от воздействия сильных волновых процессов акваториях бухтового типа на глубине до 6 м, второй в открытых морских водах относительно удаленных от берега на глубинах 20-30 м. Максимальные значения численности и биомассы $U$. pusilla у берегов Крыма не превышали соответственно 58 экз./ $\mathrm{M}^{2}$ и 53 г/м². На крымском побережье она формировала поселения в рамках пяти биоценотических комплексов: I - Heteromastus filiformis + Bittium reticulatum; II - Upogebia pusilla + Abra segmentum + Loripes orbiculatus; III - Mytilaster lineatus + Pisidia longimana; IV - Pitar rudis + Chamelea gallina + 
Upogebia pusilla и V — Mytilus galloprovincialis. B рамках EUNIS habitat classification дано описание биотопов, в которых происходит развитие поселений U. pusilla.

\section{Introduction}

Upogebia pusilla (Petagna, 1792) ("mud shrimp", upogebia and Russian "sea mole") is a representative of the Black Sea crustacean fauna (class Crustacea, order Decapoda) that refers to the infra-order Gebiidea according to the recent revision [Robles et al., 2009; De Grave et al., 2009]. Distribution range of U. pusilla covers the North-East Atlantic, the Mediterranean, Adriatic, Aegean, Red, Black and Azov seas [Makarov, 2004], where it lives from the intertidal zone to $45 \mathrm{~m}$ depth [Popovici, 1940] at salinity from 9 to 36\% [Dworschak, 1987].

The maximum body length of $U$. pusilla is up to 8 $\mathrm{cm}$ [Marin, 2013], not exceeding $6.7 \mathrm{~cm}$ off the coast of Crimea [Revkov et al., 2019]. With regard to feeding mode, this species is referred to benthic seston feeders [Dworschak, 1987a]. It is a bentho-pelagic species, that builds the burrows of 4 to $82 \mathrm{~cm}$ depth in bottom sediments [Makarov, 2004]. In process of filtration, U. pusilla creates a water current through the burrows system that is comparable to tidal conditions; it ranges from 5 to $900 \mathrm{ml} / \mathrm{h}$ depending on the size of the animal [Dworschak, 1981]. This results in forced aeration of bottom sediments that in turn determines the development of concomitant oxyphilic fauna in the area of contact the bottom sediments with burrows of upogebia and increasing the depth of its penetration into the sediment layer. Such an environmental role of upogebia in the water-sediment interface has determined its assignment to a specific group of organisms - bioturbators and "ecosystem engineers" [Posey, 1986, Posey et al., 1991].

The ecological significance and relative rarity of $U$. pusilla became the reason for its listing in "Black Sea Red Data Book" (subregional EN status (endangered - the species is facing an extremely high risk of extinction in the wild)) [Dumont, 1999], "Red Data Book Black Sea, Turkey" (EN status) [Öztürk et al., 2013], "Red Data Book of Ukraine" (EN status) [Makarov, 2009] and regional "Red Data Book of Sevastopol" (as a species decreasing in abundance) [Revkov, Revkova, 2018]. It is included in the Red Data list of Romania with LC status (least concern - there are no current identifiable risks to the species) [Micu, Micu, 2006]. A specific biotope with the dominance of $U$. pusilla has been identified in the "European Red List of Habitats" " "Pontic lower infralittoral thalassiniddominated muddy sands with Upogebia pusilla and sparse macrofauna" (A5.24A)) [Gubbay et al., 2016].

The possibility of formation of $U$. pusilla settlements on the soft bottoms in the upper benthal in various communities is long time known for the Black Sea [Zernov, 1913; Arnoldi, 1949; Milovidova, 1966, 1967;
Kiseleva, 1981; Marinov, 1990; Povchun, 1992; Nikolaenko, Povchun, 1993; Zolotarev et al., 1995; Kiseleva et al., 1999; Revkov et al., 2002, 2014, 2015; Karacuha et al., 2009; etc.]. Recent studies indicate the recovery trends of $U$. pusilla population in the Black Sea (and in the Crimean coastal zone in particular) after its depressive state during the ecological crisis of the Black Sea ecosystem of the second half of the $20^{\text {th }}$ century [Micu, Micu, 2006; Revkov et al., 2019]. In some cases, $U$. pusilla has become one of the dominant benthic species in particular areas of the Crimean [Revkov et al., 2015], Caucasian [Zolotarev, Terentyev, 2012], Bulgarian [Todorova et al., 2008; Trayanova et al., 2011] and Romanian coastal zones [Micu, Micu, 2006].

The aim of this study was to clarify the spatial distribution and evaluation of biocoenotic structure and habitat ordination for the U. pusilla settlements near the Black Sea coast of Crimea.

\section{Material and methods}

The work was based on materials from the database of the Benthos Ecology Department of the A.O. Kovalevsky Institute of Biology of the Southern Seas of RAS (1170 stations in total) collected in 1957-2013 near the Black Sea coast of Crimea (868 stations in the open coastal areas, 263 stations in the closed water areas, sheltered to the intense wave impact) and in the Central zone of the north-western Black Sea at Zernov Phyllophora Field (39 stations) within a depth range of 1-52 m. In the shallow water zone, the samples were taken by a manual sampler (with areas of 0.1 and 0.04 $\mathrm{m}^{2}$ ), at depths more than $20 \mathrm{~m}$ - using the "Ocean-50" grab (with area of $0.25 \mathrm{~m}^{2}$ ) during the cruises aboard research vessels "Professor Vodyanitsky" and "Academician A. Kovalevsky". When describing the quantitative representation of benthic fauna, the parameters of abundance, wet biomass, index functional abundance (IFA) and species density index (DI) were used:

$$
\mathrm{DI}=\mathrm{IFA} \times \mathrm{p} \quad \mathrm{IFA}=\mathrm{N}_{\mathrm{i}}{ }^{0.25} \times \mathrm{B}_{\mathrm{i}}^{0.75},
$$

where: $\mathrm{N}_{\mathrm{i}}$ - abundance (ind. $/ \mathrm{m}^{2}$ ); $\mathrm{B}_{\mathrm{i}}$ - wet biomass $\left(\mathrm{g} / \mathrm{m}^{2}\right)$ of taxa $\mathrm{i} ; \mathrm{p}$ - occurrence of taxa i (from 0 till 1 ) in the corresponding biocoenotic complex.

Only those stations (39 stations out of the total number of material studied) where U. pusilla was present were included in the biocoenotic analysis. Multivariate statistical algorithms were used to assess the structural organisation of macrozoobenthos. Data processing was performed in the PRIMER software package [Clarke, 1993; Clarke, Gorley, 2001]. Identification of the biocoenotic complexes (Cluster analysis) and their ordination (MDS analysis) were performed using a transformed (species presence/absence) station data matrix. The Bray-Curtis statistics [Bray, Curtis, 1957] was used as a measure for similarity. Determining the characteristic species of the selected spatial benthic groupings (complexes) was realized based on their contribution (according to the non-transformed 


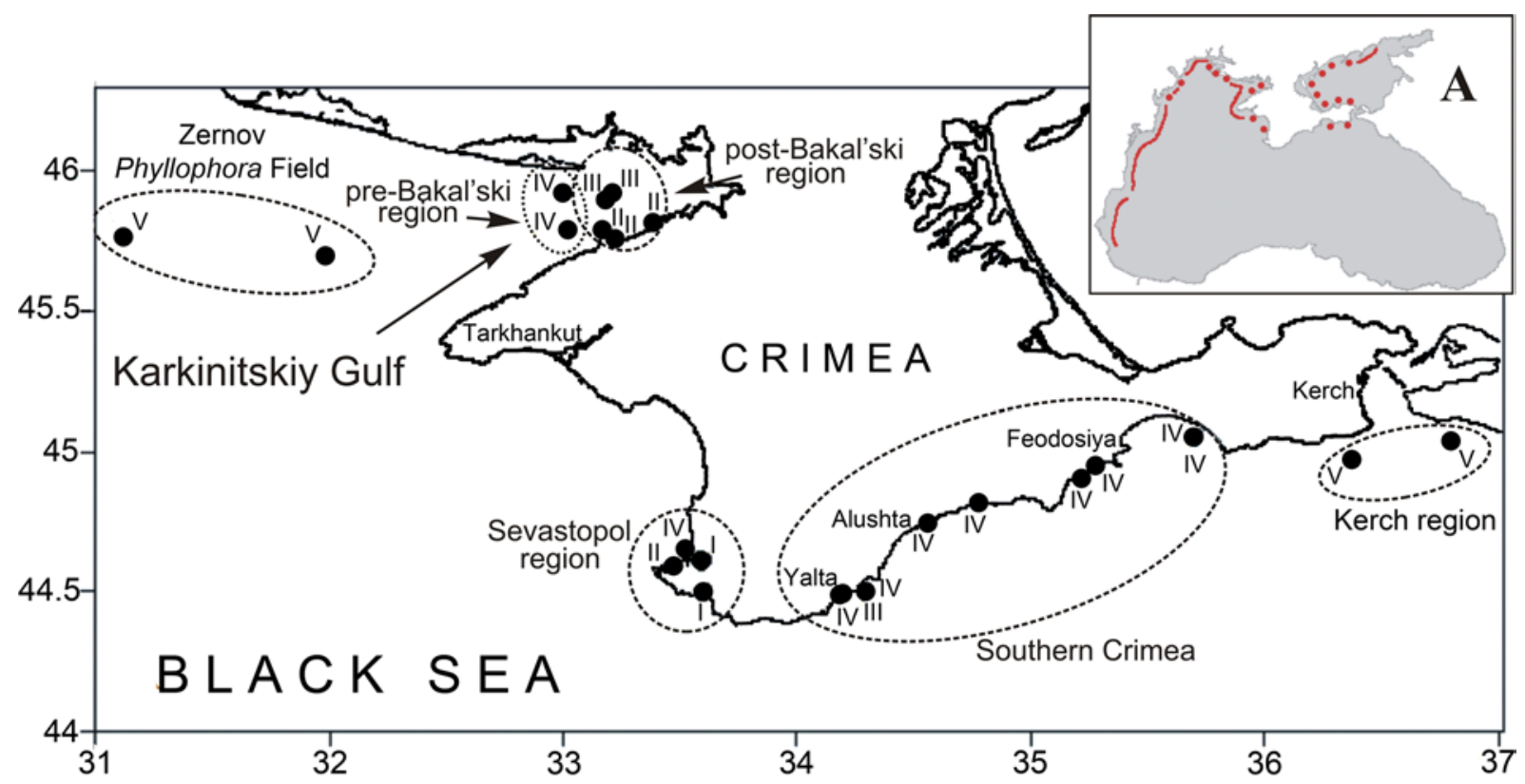

Fig. 1. Map of the stations near the coast of Crimea, where Upogebia pusilla was present. The stations affiliation to the corresponding clusters is noted (see Fig. 4). A - distribution of $U$. pusilla habitats along the northern and western coast of the Black Sea, according to Konsulova [1999].

Рис. 1. Карта станций у берегов Крыма, где встречена Upogebia pusilla. Указана принадлежность станций к соответствующим кластерам (см. рис. 4). А - распределения поселений U. pusilla у северных и западных берегов Чёрного моря по Консуловой [1999].

IFA values) to the intracomplex similarity (SIMPER analysis). The EUNIS Habitat classification [Davies et al., 2004] was used in assessing the habitat ordination for $U$. pusilla settlements.

\section{Results and discussion}

Upogebia pusilla was recorded at the stations that are located in pre-Bakal'sky (2 stations) and postBakal'sky (6 stations) sections of Karkinitsky Gulf, at Zernov Phyllophora Field (2 stations), on the southern coast of Crimea (12 stations), in the Kerch region (2 stations), in the Sevastopol region including estuary of Belbek river (1 station), Sevastopolskaya (6 stations), Streletskaya (1 station) and Balaklavskaya bays (7 stations) (Fig. 1). These materials allowed to complement the known scheme of the upogebia distribution [Konsulova, 1999] by the zones of the Sevastopol region and southern coast of Crimea. The integration of the two presented schemes, including special studies of the Decapoda in Sevastopol region [Timofeev, Anosov, 2016], indicates the existence of $U$. pusilla settlements as belt along the entire Crimea coastal zone.

ABUNDANCE AND BIOMASS. The upper limits of quantitative representation of $U$. pusilla by abundance and biomass were similar in the different sites along the coast of Crimea. In the period from the 1930s to the present, their absolute maximums were reached in the bays and were respectively 58 ind. $/ \mathrm{m}^{2}$ (Balaklavskaya bay, 2006, our data) and $52.3 \mathrm{~g} / \mathrm{m}^{2}$ (Kazach'ya bay, 2006 [Tikhonova, Alemov, 2012]). Lower values were recorded in the relatively shallow-water of postBakal'sky section of Karkinitsky gulf -8.38 ind. $/ \mathrm{m}^{2}$ and $13.68 \mathrm{~g} / \mathrm{m} 2$ (1994, [Zolotarev et al., 1995]). For the open coast areas, the corresponding maximum values of indices were found in the pre-Bakal'sky sections of Karkinitsky gulf - only 4.3 ind./m² (1934-1938, [Arnoldi, 1949]) and $3.96 \mathrm{~g} / \mathrm{m}^{2}$ (2011, our data), in the Zernov Phyllophora Field - only 4 ind. $/ \mathrm{m}^{2}$ and $0.05 \mathrm{~g} /$ $\mathrm{m}^{2}$ (2010, 2011, our data), on the southern coast of Crimea - 30 ind. $/ \mathrm{m}^{2}$ and $25.72 \mathrm{~g} / \mathrm{m}^{2}$ (1957-2013, our data), in the Kerch region - 2 ind. $/ \mathrm{m}^{2}$ and $3.88 \mathrm{~g} / \mathrm{m}^{2}$ (1980, [Nikolaenko, Povchun, 1993]).

The population density and biomass of $U$. pusilla on the southern coast of Crimea for the period from 1957 till 2013 (at 11 stations) amounted in average 10 ind. $/ \mathrm{m}^{2}$ and $7.711 \mathrm{~g} / \mathrm{m}^{2}$ respectively, with corresponding averages for the total macrozoobenthos of 3748 ind. $/ \mathrm{m}^{2}$ and $85.390 \mathrm{~g} / \mathrm{m}^{2}$. Its abundance and biomass ranks in the total macrozoobenthos species list were 31 and 6 respectively.

Similar levels of population density and biomass of $U$. pusilla (not exceeding the values for Crimea) were reported for the Caucasian coast. Its abundance and biomass reached there, respectively, 16 ind. $/ \mathrm{m}^{2}$ and $9.95 \mathrm{~g} / \mathrm{m}^{2}$ (1957-1963, depth 25-27 m, [Kiseleva, 1981]), 4-39.2 ind. $/ \mathrm{m}^{2}$ and $10.36-70.48 \mathrm{~g} / \mathrm{m}^{2}$ (Gudauta Bank, 1990, depth 10-30 m, [Zolotarev, Terentyev, 2012]). Relatively low population density and biomass of upogebia ( 2 ind $/ \mathrm{m}^{2}$ and $16.58 \mathrm{~g} / \mathrm{m}^{2}$ ) were known for the upper infralittoral zone (2-4 m deep) with Zostera spp. on the Turkish coast (Sinop region), where 

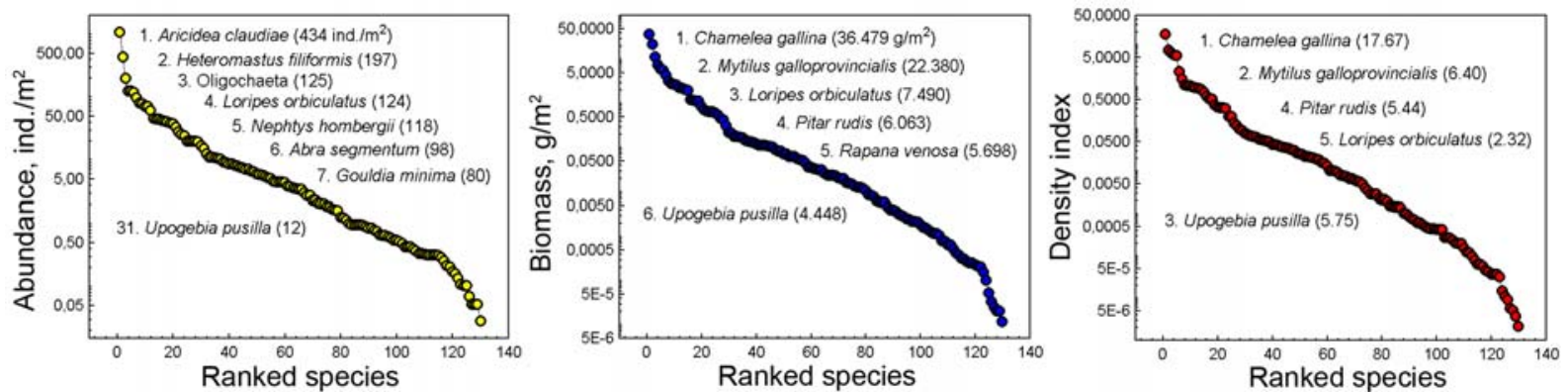

Fig. 2. The species list ranked by Biomass, Abundance and Density Index on stations where Upogebia pusilla was present.

Рис. 2. Список видов, ранжированных по численности, биомассе и индексу плотности на станциях с Upogebia pusilla.

A

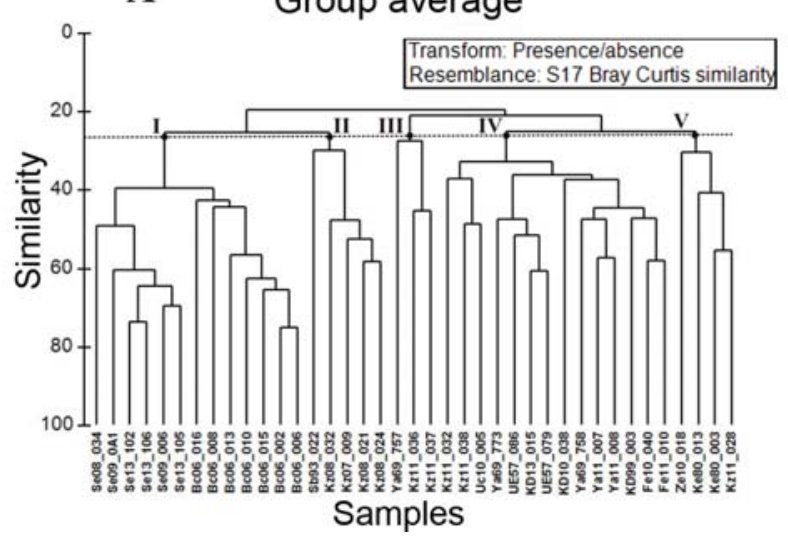

B

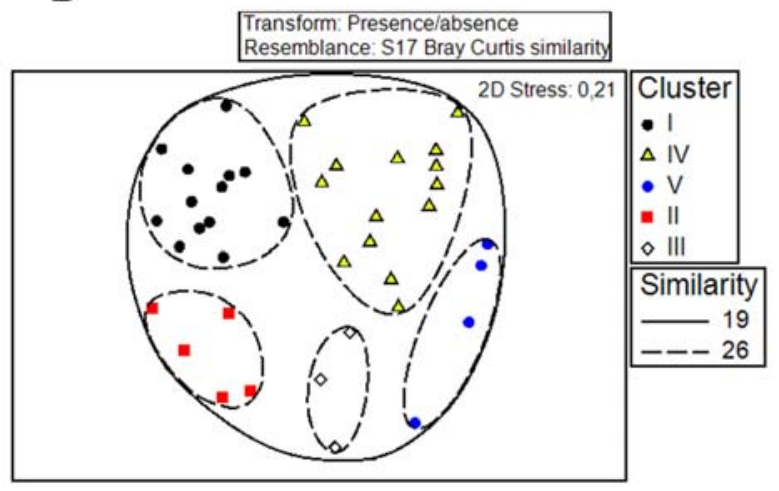

Fig. 3. Hierarchical clustering (A) and 2D-ordination (B) of 39 benthic stations at the coast of Crimea, where Upogebia pusilla was present. The station numbers are given according to their designations in the database used.

Рис. 3. Иерархическая кластеризация (А) и 2D-ординация (B) 39 бентосных станций у берегов Крыма, где встречена Upogebia pusilla. Номера станций приводятся в соответствии с их обозначениями в использованной базе данных.

U. pusilla was a common benthic species [Karacuha et al., 2009]. On the Bulgarian coast (Varna Bay, 20082009), the maximum values of its abundance and biomass reached respectively $140 \mathrm{ind} . / \mathrm{m}^{2}$ and $62.7 \mathrm{~g} / \mathrm{m}^{2}$ (depth $16.5 \mathrm{~m}$ ); it was a dominant species in benthic communities there, locally forming its own biocoenosis [Todorova et al., 2008; Trayanova et al., 2011].

UPOGEBIA IN THE OVERALL QUANTITATIVE STRUCTURE OF MACROZOOBENTHOS. Upogebia pusilla is not the mass taxa of benthos near the Black Sea coast of Crimea. At the exposed coastal zone of Crimea ( 868 stations, depths 1-52 m) it holded only $78^{\text {th }}$ position in the species list ranked by DI (DI = 0.004 ; found at $3 \%$ of stations); in the bays and inlets (263 stations) it was on the $65^{\text {th }}$ place $(0.008$ and $5 \%$ respectively), in the area of Zernov Phyllophora Field on the rank was $82(0.00005$ and $3 \%$ respectively) [Revkov et al., 2019].

If we consider only stations with the presence of mud shrimp, its DI rating goes up significantly (Fig. 2). The rank of the mud shrimp by DI was only three digits below the rank of bivalve mollusks Chamelea gallina and Mytilus galloprovincialis (Fig. 2). There is no doubt that the last two species, "competing" with U. pusilla in the biotope that it occupies, also find favorable conditions here. The average biomass of one of the most abundant species in the Black Sea benthic communities, Ch. gallina, is presented by only $36.5 \mathrm{~g} /$ $\mathrm{m}^{2}$ at the stations with $U$. pusilla, while in general it is one order of magnitude higher for this species at the coast of Crimea in the depth ranges $0-10 \mathrm{~m}(\sim 300 \mathrm{~g} /$ $\left.\mathrm{m}^{2}\right), 10-20(\sim 250), 20-30(\sim 120)$, given for the period 1980-1990 [Revkov et al., 2008]. The similar remark can be made in relation to $M$. galloprovincialis whose average biomass in the considered station complex with U. pusilla is $22.380 \mathrm{~g} / \mathrm{m}^{2}$, and it is below the known averages for mussels off the coast of the Crimea in the depth ranges of $0-10 \mathrm{~m}\left(\sim 70 \mathrm{~g} / \mathrm{m}^{2}\right), 10-20(\sim 130)$, 20-40 ( 320). Therefore, we assume the presence of specific conditions in the habitat of $U$. pusilla that make it suboptimal for Ch. gallina and M. galloprovincialis. We suppose that the factor negatively affecting the abundance of dominant bivalves is the filtration activity of upogebia, which reduces the larvae settling and the development of other seston feeders competing with it, such as Ch. gallina and M. galloprovincialis.

BIOCOENOTIC ORDINATION. The composition of the benthic macrofauna was not uniform in the areas, where U. pusilla inhabits. Five clusters (complexes) of stations have been identified off the coast of 
Table 1. List of main species in biocoenotic complexes with Upogebia pusilla presence ranked by contribution to the intracomplex similarity.

Табл. 1. Ранжированные (по вкладу во внутрикомплексное сходство) списки основных видов в биоценотических комплексах с участием Upogebia pusilla.

\begin{tabular}{|c|c|c|c|c|c|}
\hline Species & Av. IFA & $\bar{\alpha}_{i}$ & $\bar{\alpha}_{\mathrm{i}} / \mathrm{SD}\left(\alpha_{\mathrm{i}}\right)$ & $\bar{\alpha}_{\mathrm{i}} \%$ & Cum. $\bar{\alpha}_{i} \%$ \\
\hline \multicolumn{6}{|c|}{ Complex I, Average similarity: 19.22} \\
\hline Heteromastus filiformis & 1.81 & 4.53 & 0.75 & 23.55 & 23.55 \\
\hline Bittium reticulatum & 5.80 & 4.50 & 0.49 & 23.43 & 46.98 \\
\hline Diogenes pugilator & 3.51 & 1.94 & 0.43 & 10.09 & 57.06 \\
\hline Upogebia pusilla & 1.24 & 1.84 & 0.88 & 9.58 & 66.65 \\
\hline Nephtys hombergii & 1.47 & 1.61 & 0.36 & 8.37 & 75.02 \\
\hline Oligochaeta & 0.57 & 1.36 & 0.59 & 7.10 & 82.11 \\
\hline Micronephthys stammeri & 0.44 & 0.91 & 0.90 & 4.74 & 86.85 \\
\hline Tritia pellucida & 2.31 & 0.70 & 0.35 & 3.66 & 90.51 \\
\hline \multicolumn{6}{|c|}{ Complex II, Average similarity: 13.32} \\
\hline Upogebia pusilla & 12.11 & 3.98 & 0.97 & 29.91 & 29.91 \\
\hline Abra segmentum & 46.34 & 2.58 & 0.37 & 19.36 & 49.26 \\
\hline Loripes orbiculatus & 112.24 & 2.43 & 0.51 & 18.25 & 67.51 \\
\hline Mytilaster lineatus & 3.18 & 0.80 & 1.14 & 5.98 & 73.49 \\
\hline Lagis neapolitana & 6.08 & 0.73 & 0.32 & 5.49 & 78.98 \\
\hline Molgula euprocta & 10.07 & 0.72 & 0.41 & 5.38 & 84.36 \\
\hline Nephtys hombergii & 2.66 & 0.51 & 0.47 & 3.83 & 88.19 \\
\hline Heteromastus filiformis & 2.58 & 0.35 & 0.60 & 2.61 & 90.80 \\
\hline \multicolumn{6}{|c|}{ Complex III, Average similarity: 6.84} \\
\hline Mytilaster lineatus & 30.09 & 5.10 & 0.60 & 74.55 & 74.55 \\
\hline Pisidia longimana & 36.27 & 1.28 & 0.58 & 18.76 & 93.31 \\
\hline Molgula euprocta & 4.66 & 0.19 & 0.58 & 2.73 & 96.05 \\
\hline Chamelea gallina & 0.65 & 0.13 & 0.58 & 1.86 & 97.90 \\
\hline Upogebia pusilla & 0.24 & 0.10 & 0.62 & 1.51 & 99.42 \\
\hline \multicolumn{6}{|c|}{ Complex IV, Average similarity: 17.92} \\
\hline Pitar rudis & 18.10 & 6.48 & 0.78 & 36.14 & 36.14 \\
\hline Chamelea gallina & 104.56 & 3.92 & 0.35 & 21.86 & 58.00 \\
\hline Upogebia pusilla & 6.33 & 2.84 & 0.80 & 15.83 & 73.84 \\
\hline Tritia reticulata & 3.10 & 1.56 & 0.58 & 8.71 & 82.55 \\
\hline Gouldia minima & 8.79 & 0.86 & 0.35 & 4.79 & 87.34 \\
\hline Aricidea claudiae & 1.91 & 0.42 & 0.58 & 2.35 & 89.68 \\
\hline Mytilus galloprovincialis & 15.07 & 0.38 & 0.11 & 2.13 & 91.82 \\
\hline \multicolumn{6}{|c|}{ Complex $V$, Average similarity: 13.72} \\
\hline Mytilus galloprovincialis & 124.01 & 8.44 & 1.28 & 61.50 & 61.50 \\
\hline Pitar rudis & 8.82 & 1.95 & 0.88 & 14.22 & 75.73 \\
\hline Modiolus adriaticus & 29.33 & 1.00 & 0.41 & 7.32 & 83.05 \\
\hline Polititapes aurea & 3.80 & 0.74 & 0.41 & 5.42 & 88.47 \\
\hline Upogebia pusilla & 1.67 & 0.43 & 0.44 & 3.14 & 91.61 \\
\hline
\end{tabular}

Note: Av. IFA — average index of functional abundance; $\bar{\alpha}_{i}$ - absolute and $\bar{\alpha}_{i} \%$ - relative contributions of "i"-species to the average Bray-Curtis similarity within the complex; SD — standard deviation.

Crimea at the $26 \%$ similarity level (Fig. 3). Complexes I and IV are represented by the largest number of stations.

Based on stations ordination (Fig. 3) and the mud shrimp importance in the selected station complexes (Table 1), upogebia's benthic habitats at the coast of Crimea are within five biocoenotic complexes: I Heteromastus filiformis + Bittium reticulatum; II Upogebia pusilla + Abra segmentum + Loripes orbiculatus; III - Mytilaster lineatus + Pisidia longimana; IV - Pitar rudis + Chamelea gallina + Upogebia pusilla and V - Mytilus galloprovincialis.
Upogebia pusilla was the major contributing species in the complex II $\left(\bar{\alpha}_{i}=3.98\right)$ only. Its importance was slightly less in the complex IV $\left(\bar{\alpha}_{i}=2.84\right)$, where it holded the third position following the bivalves $P$. rudis and Ch. gallina. The other complexes ranked according to decreasing contribution of upogebia were the following: I (1.84), V (0.43) and III (0.10) (Table 1). The highest upogebia biomass was also recorded at the stations of complexes II and IV (Table 2).

HABITAT ORDINATION. The settlements of $U$. pusilla on the Crimean coast were recorded at depth up to $36 \mathrm{~m}$ with two peaks of IFA values at $1-6 \mathrm{~m}$ and 
Table 2. The values of abundance and biomass of Upogebia pusilla in biocoenotic complexes near the Black Sea coast of Crimea.

Таблица 2. Численность и биомасса Upogebia pusilla в различных биоценотических комплексах у Черноморских берегов Крыма.

\begin{tabular}{|c|c|c|c|c|c|}
\hline Complex & $\begin{array}{c}\text { No. of } \\
\text { stations }\end{array}$ & Years & Depth, $\mathrm{m}$ & $\begin{array}{c}\text { Abundance, } \\
\text { ind./m }\end{array}$ & Biomass, $\mathrm{g} / \mathrm{m}^{2}$ \\
\hline I & 13 & $2006,2008,2009,2013$ & $5-22(11)$ & $8-58(21)$ & $0.021-4.517(0.627)$ \\
II & 5 & $1993,2007,2008$ & $1-6(3)$ & $13-14(13)$ & $0.838-26.688(13.005)$ \\
III & 3 & 1969,2011 & $10-11(10)$ & $4-8(5)$ & $0.0004-0.182(0.109)$ \\
IV & 14 & $1957,1969,1999,2010$, & $11-30(22)$ & $2-30(8)$ & $0.0004-25.720(6.592)$ \\
V & 4 & $1980,2010,2013$ & $22-36(28)$ & $2-4(3)$ & $0.018-3.880(1.917)$ \\
\hline
\end{tabular}

Note: the average values of the parameters are indicated in brackets.

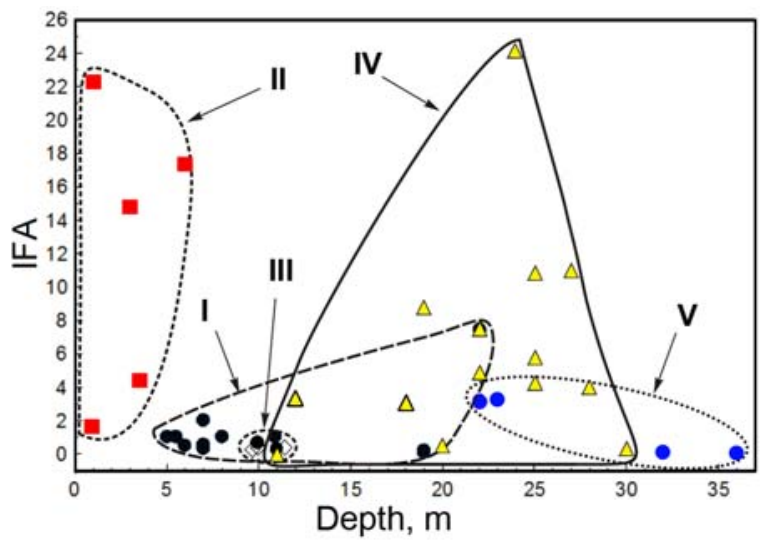

Fig. 4. Graph of index of functional abundance (IFA) of Upogebia pusilla and biocoenotic complexes (I-V, see Fig. 3) as a function of depth at the coast of Crimea.

Рис. 4. График зависимости индекса функционального обилия (IFA) Upogebia pusilla и биоценотических комплексов (IV, см. рис. 3) от глубины у берегов Крыма.

20-30 m (Fig. 4). This pattern of upogebia distribution was realized within the above five biocoenotic complexes. To describe the belonging of biocoenotic complexes to certain biotopes, we used the known European scheme of marine habitats classification (EUNIS habitat classification) [Davies et al., 2004].

Sixty-four biotopes (level 4; according to EU28+) were described in the Black Sea. One of them has the status of CR (Critically Endangered), while 2 are EN (Endangered), 3 are VU (Vulnerable), 1 is NT (Near Threatened), 2 are LC (Least Concern) and 54 are DD (Data Deficient) [Gubbay et al., 2016]. At the same time in the poorly investigated (DD status) biotope A5.24 ("Pontic infralittoral muddy sand") the habitat with U. pusilla was indicated as A5.24A ("Pontic lower infralittoral thalassinid-dominated muddy sands with Upogebia pusilla and sparse macrofauna") with the status of LC.

According to the principles outlined by Davies et al. [2004], biological criteria is the main for determining biotopes, starting from the fifth level of marine habitat classification. Due to the revealed biocoenotic complexes, we propose the following identification of habitats where $U$. pusilla lives.
Biocoenotic complex of Heteromastus filiformis + Bittium reticulatum. The proposed habitat code is A5.34x "Pontic soft stable infralittoral muds in bays with Upogebia pusilla". This habitat is restricted to the most sheltered areas with physically stable muds, and in our survey was located in Balaklavskaya bay and in the inner part of Sevastopolskaya bay at a depth of 5$22 \mathrm{~m}$. Along with the main complex-forming species, polychaete Heteromastus filiformis and gastropod Bittium reticulatum, which were characterised by an abundance, biomass and occurrence of 246 ind. $/ \mathrm{m}^{2}, 0.366$ $\mathrm{g} / \mathrm{m}^{2}, 100 \%$ and 175 ind. $/ \mathrm{m}^{2}, 1.944 \mathrm{~g} / \mathrm{m}^{2}, 69 \%$ respectively, the characteristic species included the polychaetes Micronephthys stammeri (123, 0.070, 100), Capitella capitata $(66,0.056,62)$, Oligochaeta $(251,0.075$, $85)$, crustaceans Upogebia pusilla $(21,0.627,100)$ and Diogenes pugilator $(46,1.819,54)$ with the occurrence of $50 \%$ or more.

Biocoenotic complex of Upogebia pusilla + Abra segmentum + Loripes orbiculatus. The proposed habitat code is A5.24x "Pontic upper infralittoral thalassiniddominated muddy sands with Upogebia pusilla". This complex is restricted to the upper infralittoral zones at depths of 1-6 m on muddy sands with macrophytes (Zostera marina and Z. nolti) and in our survey it was located in the inner part of Streletskaya bay and in the post-Bakal'ski coastal area sheltered to the intense wave impact. Along with the main complex-forming species, Upogebia pusilla (13 ind. $\left./ \mathrm{m}^{2}, 13.005 \mathrm{~g} / \mathrm{m}^{2}, 100 \%\right)$, bivalves Loripes orbiculatus $(958,56.11,80)$ and Abra segmentum $(700,21.753,80)$, the characteristic species included bivalves Mytilaster lineatus (211, 0.949, $100)$, Parvicardium exiguum $(39,2.04,80)$, the polychaetes Heteromastus filiformis $(360,0.500,80)$, Melinna palmata (150, 1.32, 60), Nephtys hombergii (21, $1.349,60)$, amphipod crustacean Microdeutopus gryllotalpa $(336,0.203,60)$, Oligochaeta $(277,0.056,80)$ and the ascidian Molgula euprocta $(40,8.158,60)$ with the occurrence of $50 \%$ or more.

Biocoenotic complex of Mytilaster lineatus $+\mathrm{Pi}$ sidia longimana. The proposed habitat code is A5.43x "Pontic upper infralittoral mixed sediments with Mytilaster lineatus". This complex is restricted to the upper infralittoral zone in offshore areas with good water 
exchange at depths $10-11 \mathrm{~m}$. The sediments of this habitat represented by combination of silt, sand and shells, allowing forming both of benthic macro-, epiand infauna, including settlements of burrowing U. pusilla. This complex was located in Yalta coastal area and in the post-Bakal'sky part of Karkinitsky gulf opened to intensive wave impact. Along with the main complex-forming species, bivalve Mytilaster lineatus (88 ind. $/ \mathrm{m}^{2}, 23.185 \mathrm{~g} / \mathrm{m}^{2}, 100 \%$ ) and decapod crustacean Pisidia longimana $(47,35.283,66)$, the characteristic species included the bivalve Chamelea gallina $(5,0.324,66)$, the crustaceans Upogebia pusilla (5, 0.109, 100), Amphibalanus improvisus $(5,10.475,66)$ and the ascidian Molgula euprocta (531, 1.053, 66), with the occurrence of $50 \%$ or more.

Biocoenotic complex of Pitar rudis + Chamelea gallina + Upogebia pusilla. This complex is restricted to the open coastal zone of the Southern Crimea and offshore the pre-Bakal'ski region of Karkinitski Gulf at depths $11-30 \mathrm{~m}$, where the wave impact slightly affects to destroy of $U$. pusilla burrows. The sediments were sandy muds and muddy sands sometimes mixed with shell hash. This habitat is "composite" and represented by the already known "Pontic lower infralittoral thalassinid-dominated muddy sands with Upogebia pusilla and sparse macrofauna" (A5.24A) [Gubbay et al., 2016], and by the new "Pontic upper circalittoral thalassinid-dominated sandy muds with Upogebia pusilla" (A5.35x). Along with the typical representatives of the sandy muds, the bivalves Pitar rudis (94 ind. $/ \mathrm{m}^{2}$, $\left.13.740 \mathrm{~g} / \mathrm{m}^{2}, 100 \%\right)$, Gouldia minima $(221,3.189,71)$, Acanthocardia paucicostata (35, 0.318, 57), Spisula subtruncata (49, 2.362, 50), Abra nitida (28, 0.077, 50) and the polychaete Aricidea claudiae (1209, 0.303, $71)$, the characteristic species included those that can't withstand substrate siltations: the bivalves Chamelea gallina $(181,90.969,79)$ and Lucinella divaricata $(105$, $0.337,50)$. The abundance, biomass and occurrence of Upogebia pusilla reached here 8 ind. $/ \mathrm{m}^{2}, 6.592 \mathrm{~g} / \mathrm{m}^{2}$ and $100 \%$ respectively (Table 1 ).

Biocoenotic complex of Mytilus galloprovincialis. According to the surveys of the macrozoobenthos assemblages structure [Revkov, Boltacheva, 2021], in the water area of the Zernov Phyllophora Field, biocoenotic complex of Mytilus galloprovincialis is located on "Pontic circalittoral biogenic detritic bottoms with dead or alive mussel beds, shell deposits, with encrusting corallines (Phymatolithon, Lithothamnion) and attached foliose sciaphilic macroalgae" (A5.62x). This complex was detected both in the water area of the Zernov Phyllophora Field and in the Kerch region (Fig. 1), at depths 22-36 m, where the wave impact on bottom landscapes are affected rarely and slightly. The sediments were mixed (mud, sand and shells) with a predominance of mussel shells. Along with the main complex-forming species, Mytilus galloprovincialis (15 ind. $/ \mathrm{m}^{2}, 131.285 \mathrm{~g} / \mathrm{m}^{2}$ and $100 \%$ ), in these local habitat (with the presence of $U$. pusilla) the characteristic species included the mollusks Calyptraea chinensis (18,
$1.234,75)$, Pitar rudis $(13,8.919,75)$, Tritia reticulata (96, 1.86, 50), Modiolus adriaticus (24, 31.586, 50), Polititapes aurea $(4,4.376,50)$ and the ascidian Ascidiella aspersa $(3,5.286,50)$. The abundance, biomass and occurrence of Upogebia pusilla reached here 2, $1.917,100$ respectively. Due to the bordering of this local habitat with the phaseolina silts zone, some characteristic species of lower circalittoral muds - the amphiurans Amphiura stepanovi $(48,0.686,75)$ and bivalve Modiolula phaseolina $(388,19.681,25)$ were presented here.

\section{Conclusion}

Upogebia pusilla is not the mass benthos taxa near the Black Sea coast of Crimea and it does not rise above $65^{\text {th }}$ place in the species list ranked by Density Index here. Nevertheless, it is a common species for the Crimean water areas. Studies performed indicates the existence of $U$. pusilla settlements as a belt along the entire Crimean coastal zone in the depth range of 1-36 $\mathrm{m}$ with two peaks of quantitative representation at $1-6 \mathrm{~m}$ and $20-30 \mathrm{~m}$. The values of its abundance and biomass don't exceed 58 ind. $/ \mathrm{m}^{2}$ and $53 \mathrm{~g} / \mathrm{m}^{2}$, respectively.

The presence of suitable soft sediments (mud, sand, shells debris and their various combinations) and its physical stability are necessary conditions for the formation of $U$. pusilla settlements. The last one are achieved both in shallow water areas (bays and inlets) sheltered to the intense wave impact and at the exposed coastal and offshore zones, but deeper, where the wave impact to destroy of $U$. pusilla burrows affects slightly.

Upogebia pusilla is a part of the five biocoenotic complexes located in six bottom habitats of the sublittoral zone along the coast of Crimea and is one of the main complex-forming species in two of them. These are the complexes of Upogebia pusilla + Abra segmentum + Loripes orbiculatus ("Pontic upper infralittoral thalassinid-dominated muddy sands with Upogebia pusilla" habitat) and of Pitar rudis + Chamelea gallina + Upogebia pusilla (mix of two habitats - "Pontic lower infralittoral thalassinid-dominated muddy sands with Upogebia pusilla and sparse macrofauna" and "Pontic upper circalittoral thalassinid-dominated sandy muds with Upogebia pusilla").

Acknowledgements. Authors deeply thanks V.A. Spiridonov, whose suggestions and comments improved the manuscript. The work was conducted within the framework of the Russian Academy of Sciences research assignment, State registration No 121030100028-0.

Compliance with ethical standards

Conflict of Interest: The authors declare that they have no conflict of interest.

Ethical approval: No ethical issues were raised during our research. 


\section{References}

Arnoldi L.V. 1949. [Materials on the quantitative study of the zoobenthos of the Black Sea. II Karkinitsky Gulf] // Trudy Sevastopol'skoy Biologycheskoy Stantsii. M.-L.: Izdatel'stvo AN SSSR. Vol.7. P.127-192 [in Russian].

Bray J.R., Curtis J.T. 1957. An ordination of the upland forest communities of South Wiskonsin // Ecol. Monogr. Vol.27. P.325-347.

Clarke K.R. 1993. Non-parametric multivariate analyses of changes in community structure // Aust. J. Ecol. Vol.18. Đ.117-143.

Clarke K.R., Gorley R.M. 2001. PRIMER v5: User Manual / Tutorial. Primer-E: Plymoith. 92 p.

Davies C.E., Moss D., O'Hill M. 2004. EUNIS Habitat Classification Revised 2004 // Report to the European Topic Centre on Nature Protection and Biodiversity, European Environment Agency, October 2004. 307 p.

De Grave S., Pentcheff N.D., Ahyong S.T., Chan T.-Y., Crandall K.A., Dworschak P.C., Felder D.L., Feldmann R.M., Fransen C.H.J.M., Goulding L.Y. D., Lemaitre R., Low M.E.Y., Martin J.W., Ng P. K.L., Schweitzer C.E., Tan S.H., Tshudy D., Wetzer R. 2009. A classification of living and fossil genera of Decapod crustaceans // Raffles Bull. Zool. Suppl.. No.21. P.1-109.

Dumont H.J. (ed.). 1999. Black Sea Red Data Book. Published by the United Nations Office for Project Services. $413 \mathrm{p}$.

Dworschak P.C. 1981. The pumping rates of the burrowingshrimp Upogebia pusilla (Petagna) (Decapoda, Thalassinidae) // J Exp. Mar. Biol. and Ecol. Vol.52. No.1. P.25-35.

Dworschak P.C. 1987. The biology of Upogebia pusilla (Petagna) (Decapoda, Thalassinidea) II. Environments and zonation / P.S.Z.N.I.: Marine Ecology. Vol.8. No.4. P.337-358.

Dworschak P.C. 1987a. Feeding behaviour of Upogebia pusilla and Callianassa tyrrhena (Crustacea, Decapoda, Thalassinidea) // Inv. Pesq. Vol.51 (Supl. 1). P.421-429.

Gubbay S., Sanders N., Haynes T., Janssen J.A.M., Rodwell J.R., Nieto A., Garcia Criado M., Beal S., Borg J., Kennedy M., Micu D., Otero M., Saunders G., Calix M. 2016. European Red List of Habitats. Part 1. Marine habitats. Luxembourg: Publications Office of the European Union. 52 p. doi: 10.2779/ 032638 .

Karacuha E., Sezgin M., Da li E. 2009. Temporal and spatial changes of crustaceans in mixed eelgrass beds, Zostera marina L. and Z. noltii Hornem., at the Sinop peninsula coast (the southern Black Sea, Turkey) // Turk. J. Zool. Vol.33. P.375386.

Kiseleva M.I. 1981. [Benthos of the soft bottoms of the Black Sea]. Kiev: Naukova dumka. 165 p. [In Russian]

Kiseleva M.I., Revkov N.K., Kopytov Y.P. 1999. Modern state and long-term changes in zoobenthos of the Streletskaya bight (Sevastopol region) // Hidrobiological journal. Vol.35. No.1. P.85-97.

Konsulova T. 1999. Upogebia pusilla (Petagna, 1792) // H.J. Dumont (ed.). Black Sea Red Data Book. Published by UNOPS. P.379-381.

Makarov Yu.N. 2004. [Fauna of Ukraine. Volume 26. Higher crustaceans. 1-2, Decapoda]. Kiev: Naukova Dumka. 429 p. [In Russian]

Makarov Yu.M. 2009. [Sea mole Upogebia pusilla (Petagna, 1792)] // Chervona kniga Ukrayoni. Tvariynniy svit. Kyiv: Vidavnitstvo "GlobalConsulting". P.43 [in Ukranian].

Marin I.N. 2013. [The small atlas of Decapoda of Russia]. Moscow: KMK Scientific Press. 145 p. [In Russian]

Marinov T.M. 1990. The zoobenthos from the Bulgarian sector of the Black sea. Sofia: Pablishin House of the Bulgarian Academy of Sciences. 195 p. [In Bulgarian]

Micu S., Micu D. 2006. Proposed IUCN regional status of all CRUSTACEA: DECAPODA from the Romanian Black Sea // Analele Științifice ale Universității „AL. I. CUZA” Iaşi, s. Biologie animal. T.52. P.7-38

Milovidova N.Yu. 1966. [Bottom biocoenoses of Novorossiysk bay] // Raspredelenie bentosa i biologiya donnykh zhivotnykh v uzhnikh moryakh. Kiev: Naukova Dumka. P.75-89 [in Russian].
Milovidova N.Yu. 1967. [Bottom biocoenoses of the bays of the north-eastern part of the Black Sea] // Biologiya morya. P.317 [in Russian].

Nikolaenko T.V., Povchun A.S. 1993. [Benthos of the Kerch PreStrait] // Ecologiya morya. Vol.44. P.46-51 [in Russian].

Öztürk B., Oral M., Toplao lu B., Bat L., Okudan Aslan E. ., Özgür Özbek E., Sezgin M., Tonay A.M., Amaha Öztürk A., sfendiyaro lu S., Uysal . 2013. Red Data Book Black Sea, Turkey. Published by TUDAV, stanbul Turkey. 323 p.

Popovici Z. 1940. Langenmessungen an Upogebia littoralis R. aus dem Schwarzen Meere // Bull. Sect. Sci. Acad. Roumaine. T.22. P.484-488.

Posey M.H. 1986. Predation on a burrowing shrimp: distribution and community consequences // J. Exp. Mar. Biol. Ecol. Vol.103. P.143-161.

Posey M.H., Dumbauld B.R., Armstrong D.A. 1991. Effects of a burrowing mud shrimp, Upogebia pugettensis (Dana), on abundances of macro-infauna // J. Exp. Mar. Biol. Ecol. Vol.148. P.283-294.

Povchun A.S. 1992. [Changes in the benthic communities of the Karkinitsky Gulf] // Mnogoletnie izmeneniya zoobentosa Chernogo morya. Kiev: Naukova dumka. P.105-138 [in Russian]

Revkov N.K., Abaza V., Dumitrache C., Todorova V., Konsulova T., Mickashavidze E., Varshanidze M., Sezgin M., Ozturk B., Chikina M.V., Kucheruk N.V. 2008. The state of zoobenthos // State of the Environment of the Black Sea (2001-2006/7). Edited by Temel Oguz. Publications of the Comission on the Protection of the Black Sea Against Pollution (BSC) 2008. 3. Istanbul, Turkey. P.273-320.

Revkov N.K., Boltachova N.A. 2021. Structure of the macrozoobenthos assemblages in the central part of the northwestern Black Sea shelf (Zernov's Phyllophora Field) at the beginning of the $21^{\text {st }}$ century // Ecologica Montenegrina. Vol.39. P.92108. Available at: http://dx.doi.org/10.37828/em.2021.39.11.

Revkov N.K., Boltacheva N.A., Bondarev I.P., Bondarenko L.V., Timofeev V.A. 2015. [The condition of benthal zooresources in the deepwater zone of the Crimea shelf after the crisis of the Black Sea ecosystem in the second half of the 20th century (according to the data of expeditionary research 2010 on the RV "Professor Vodyanitsky")] // A.V. Gaevskaya, A.L. Morozova (eds.). 100 let Karadagskoy nauchnoy stantsii imeni T.I. Vyazemskogo. Simferopol: N. Oreanda. P.549-571 [in Russian].

Revkov N.K., Boltacheva N.A., Nikolaenko T.V., Kolesnikova E.A. 2002. Zoobenthos biodiversity over the soft bottom in the Crimean coastal zone of the Black sea // Oceanology. Vol.42. No.4. P.536-546.

Revkov N.K., Revkova T.N. 2018. [The sea mole Upogebia pusilla (Petagna, 1792)] // Red Data Book of Sevastopol. Kaliningrad - Sevastopol: Publishing House ROST-DOAFK. P.258 [in Russian].

Revkov N.K., Timofeev V.A., Lisitskaya E.V. 2014. [Composition and seasonal dynamics of macrozoobenthos of the local biotic complex Chamelea gallina (western Crimea, Black Sea)] // Optimization and Protection of Ecosystems. Published by V.I. Vernadskiy Taurida National University, Simferopol. Vol.11 (30). P.247-259 [in Russian].

Revkov N.K., Timofeev V.A., Revkova T.N. 2019. [The long-term changes of Upogebia pusilla (Crustacea: Decapoda) population on the Northern shelf of the Black Sea (Crimea)] // Ekosistemy. Iss.19. P.123-132 [in Russian].

Robles R., Tudge C.C., Dworschak P.C., Poore G.C. B., Felder D.L. 2009. Molecular phylogeny of the Thalassinidea based on nuclear and mitochondrial genes // J.W. Martin, K.A. Crandall, D.L. Felder (eds.). Decapod Crustacean Phylogenetics (Crustacean Issues). Boca Raton. FL: Taylor \& Francis/CRC. P.309-326

Tikhonova E.A., Alemov S.V. 2012. [Characteristics of bottom sediments and macrozoobenthos Kazachya bay in the first decade of the XXI century] // Ecologicheskaya bezopasnost' pribrezhnoy i shel'fovoy zon i kompleksnoe ispol'zovanie resursov shel'fa. Sevastopol. Vol.26. No.1. P.88-94 [in Russian]. 
Timofeev V.A., Anosov S.A. 2016. [The current state of the species diversity of Decapoda (Crustacea) in the bays of Sevastopol] // Morskiye biologicheskie issledovaniya: dostizheniya perspektivi. Sbornik materialov Vserossiyskoy nauchno-prakticheskoy konferentsii s mezhdunarodnim uchastiem, priurochennoy k 145-letiyu Sevastopol'skoy biologicheskoy stantsii. T.2. P.174-177 [in Russian].

Todorova V., Trayanova A., Konsulova T. 2008. Biological monitoring of coastal marine waters and lakes - benthic invertebrate fauna. Final Report of Project 'Capacity building aimed at the development of a Pilot Programme of measures for the Black Sea River Basin management plan of coastal waters at risk - Burgas and Varna bay". Black Sea Basin Directorate, Varna. 46 p.

Trayanova A.T., Todorova V.R., Konsulova T.H., Shtereva G.P. Hristova O.D., Dzhurova B.S. 2011. Ecological State of Varna
Bay in Summer 2009 according to Benthic Invertebrate Fauna // Acta zool. Bulg. Vol.63. No.3. P.277-288.

Zernov S.A. 1913. [On the question of studying the life of the Black Sea]. St. Petersburg. 280 p. [In Russian]

Zolotarev P.N., Litvinenko N.M., Terentiev A.S. 1995. [Fishery potential and seasonal dynamics in benthos of Phyllophora biocoenosis in the eastern part of the Karkinitsky bay] // Trudy Yuzhnogo nauchno-issledovatel'skogo instituta morskogo rybnogo khozyaistva i okeanografii. Vol.41 P.62-67 [in Russian].

Zolotarev P.N., Terentyev A.S. 2012. [Changes in the macrobenthic communities of the Gudauta oyster bank] // Oceanology. Vol.52. No.2. P.251-257 [in Russian].

Responsible editor V.A. Spiridonov 